\title{
PERTUMBUHAN EKONOMI REGIONAL DI INDONESIA: PERAN INFRASTRUKTUR, MODAL MANUSIA DAN KETERBUKAAN PERDAGANGAN
}

\author{
Andi Kustanto \\ Fakultas Ekonomi dan Bisnis, Universitas Sultan Ageng Tirtayasa, Banten, Indonesia \\ Email: andikustanto@outlook.com
}

\begin{abstract}
Regional Economic Growth in Indonesia: The Role of Infrastructure, Human Capital and Trade Openness. This study discusses the analysis of the impact of infrastructure development, human capital and trade openness on regional economic growth in Indonesia using the panel data method. The model was built based on the Solow growth model using road infrastructure, electricity infrastructure, health infrastructure, life expectancy, mean years of schooling and trade openness in 34 provinces in Indonesia. Estimation results obtained from this study using the fixed effects model indicate that regional economic growth in Indonesia is influenced by electricity infrastructure, health infrastructure, mean years of schooling, life expectancy, and trade openness. Whereas road infrastructure has a negative and not significant effect on regional economic growth in Indonesia. Life expectancy has the biggest impact on regional economic growth followed by mean years of schooling, health infrastructure, electricity infrastructure, and trade openness.
\end{abstract}

Keywords: Regional Economic Growth; Infrastructure; Human Capital; Trade Openness.

\begin{abstract}
Abstrak: Pertumbuhan Ekonomi Regional di Indonesia: Peran Infrastruktur, Modal Manusia dan Keterbukaan Perdagangan. Studi ini membahas tentang analisis dampak pembangunan infrastruktur, modal manusia dan keterbukaan perdagangan terhadap pertumbuhan ekonomi regional di Indonesia menggunakan metode data panel. Model yang dibangun berdasarkan model pertumbuhan Solow dengan menggunakan infrastruktur jalan, infrastruktur listrik, infrastruktur kesehatan, angka harapan hidup, rata-rata lama sekolah dan keterbukaan perdagangan di 34 provinsi di Indonesia. Hasil estimasi yang diperoleh dari penelitian ini dengan menggunakan model efek tetap menunjukkan bahwa pertumbuhan ekonomi regional di Indonesia dipengaruhi oleh infrastruktur listrik, infrastruktur kesehatan, rata-rata lama sekolah, angka harapan hidup dan keterbukaan perdagangan. Sedangkan infrastruktur jalan memberikan pengaruh negatif dan tidak signifikan terhadap pertumbuhan ekonomi regional di Indonesia. Angka harapan hidup memiliki dampak terbesar pada pertumbuhan ekonomi regional diikuti oleh rata-rata lama sekolah, infrastruktur kesehatan, infrastruktur listrik dan keterbukaan perdagangan.
\end{abstract}

Kata Kunci: Pertumbuhan Ekonomi Regional; Infrastruktur; Modal Manusia; Keterbukaan Perdagangan. 


\section{PENDAHULUAN}

Pertumbuhan ekonomi adalah salah satu indikator penting dalam melakukan analisis pembangunan dan mengukur prestasi dari perkembangan suatu perekonomian. Pertumbuhan ekonomi adalah pusat perhatian dari ilmu ekonomi makro baik secara teoritis maupun dalam aplikasinya. Pertumbuhan ekonomi tidak lain merupakan pertumbuhan Produk Domestik Bruto (PDB) suatu negara atau wilayah tertentu (Panennungi dan $\mathrm{Xu}$, 2017). Produk Domestik Bruto (PDB) sangat diperlukan dalam membandingkan tingkat kesejahteraan antarwaktu maupun antarnegara yang lebih tepatnya ketika dilihat tingkat pertumbuhannya. Peran pemerintah sebagai Indonesia dan negara anggota ASEAN seperti mobilisator pembangunan sangat strategis dalam mendukung peningkatan kesejahteraan masyarakat serta pertumbuhan negaranya (Prasetyo dan Firdaus, 2009). Bahkan, pemerintah di semua negara berlomba-lomba untuk mendapatkan pertumbuhan ekonomi tinggi dari tahun ke tahun sebagai sinyal bahwa aktivitas perekonomian negara tersebut terus mengalami kemajuan. Perencanaan pembangunan untuk menciptakan pertumbuhan ekonomi tinggi dan berkualitas antara lain melalui pembangunan infrastruktur, modal manusia dan keterbukaan perdagangan.

Berdasarkan data pada Tabel 1 dapat dilihat bahwa selisih skor infrastruktur

Tabel 1.

Kualitas Daya Saing Negara Anggota ASEAN 2017-2018 (skala 1-7)

\begin{tabular}{clccccc}
\hline No & $\begin{array}{l}\text { Nama } \\
\text { Negara }\end{array}$ & Infrastruktur & $\begin{array}{l}\text { Kesehatan dan } \\
\text { Pendidikan } \\
\text { Dasar }\end{array}$ & $\begin{array}{l}\text { Pendidikan } \\
\text { Tinggi dan } \\
\text { Pelatihan }\end{array}$ & $\begin{array}{l}\text { Ukuran } \\
\text { Pasar }\end{array}$ & $\begin{array}{l}\text { Peringkat } \\
\text { Daya Saing }\end{array}$ \\
\hline 1 & Singapura & 6.5 & 6.8 & 6.3 & 4.8 & 3 \\
2 & Malaysia & 5.5 & 6.3 & 4.9 & 5.1 & 23 \\
3 & Thailand & 4.7 & 5.5 & 4.6 & 5.2 & 32 \\
4 & Indonesia & 4.5 & 5.4 & 4.5 & 5.7 & 36 \\
5 & Brunei & 4.3 & 6.3 & 4.5 & 2.9 & 46 \\
6 & Filipina & 3.4 & 5.6 & 4.6 & 5.0 & 56 \\
7 & Viet Nam & 3.90 & 5.81 & 4.07 & 4.91 & 55 \\
8 & Kamboja & 3.14 & 5.26 & 2.88 & 3.38 & 94 \\
9 & Laos & 3.3 & 5.2 & 3.5 & 3.1 & 98 \\
\hline
\end{tabular}

Sumber: World Economic Forum: Global Competitiveness Report 2017-2018 
Singapura, Malaysia dan Thailand terpaut jauh. Jika dibandingkan dengan peringkat Global Competitiveness Index 2017-2018 dapat dilihat ada kecenderungan negara anggota ASEAN seperti Singapura, Malaysia dan Thailand memiliki peringkat daya saing tinggi. Dengan skor infrastruktur 4.5, menandakan bahwa akses layanan infrastruktur di Indonesia masih tergolong rendah. Ini mengakibatkan perekonomian kurang bisa berdaya saing dan unggul. Kurangnya kemampuan penyediaan akses layanan infrastruktur merupakan salah satu faktor yang mengakibatkan perekonomian di Indonesia berbiaya tinggi (high cost economy), di mana produsen harus menanggung beban biaya logistik tinggi, karena produksi dan distribusi kepada konsumen tidak didukung dengan akses layanan infrastruktur yang memadai seperti infrastruktur ekonomi, sosial dan administrasi.

Selain kurangnya infrastruktur yang memadai, titik lemah lain terlihat pada kualitas sumber daya manusia yang menempuh pendidikan dasar dan pendidikan tinggi dengan skor 5.4 dan 4.5, ini membuktikan bahwa kualitas pembangunan manusia yang rendah akan berdampak pada daya saing Indonesia secara keseluruhan. Untuk ukuran pasar dengan skor
5.7, bertolak belakang dengan kebijakan yang dijalankan bahwa sejak 2009, Indonesia terus meningkatkan hambatan perdagangan secara signifikan dibandingkan negara tetangganya (World Bank, 2018). Hal tersebut justru akan menghambat ekspor-impor dan investasi asing langsung untuk menambah produktivitas dan pertumbuhan ekonomi Indonesia menjadi kompetitif di kancah global.

Otto et al., (2014) mendefinisikan infrastruktur sebagai kebutuhan dasar fisik dalam mengembangkan kegunaan sektor publik melalui pelayanan barang dan jasa untuk fasilitas umum yang disediakan secara gratis atau dengan harga yang terjangkau. Tanpa infrastruktur, kegiatan produksi pada berbagai sektor kegiatan ekonomi tidak dapat berfungsi. Peran infrastruktur dalam pertumbuhan ekonomi telah menjadi tema sentral dalam lingkaran kebijakan pembangunan (Chakamera dan Alagidede, 2018). Infrastruktur yang memadai sebagai penunjang aktivitas ekonomi akan berdampak pada pertumbuhan ekonomi (Dash dan Sahoo, 2010). Pembangunan infrastruktur merupakan prasyarat bagi sektorsektor lain untuk berkembang dan sebagai sarana penciptaan hubungan antara satu dengan yang lain. Pemberdayaan sumber daya untuk 
membangun infrastruktur akan memicu proses ekonomi sehingga menimbulkan penggandaan dampak ekonomi maupun sosial.

Kualitas modal manusia yang diukur melalui pendidikan, kesehatan dan pendapatan adalah faktor yang sangat penting dalam menentukan produktivitas suatu perekonomian. Farah dan Sari (2014) mendefiniskan modal manusia sebagai dimensi kualitatif dari sumberdaya manusia. Keahlian dan keterampilan, yang dimiliki oleh seseorang akan mempengaruhi kemampuan produktif seseorang tersebut. Keahlian, keterampilan dan pengetahuan tersebut dapat ditingkatkan melalui proses pendidikan yang baik dan kondisi kesehatan yang terjaga. Pendidikan dan kesehatan memainkan peran potensial dalam pengembangan suatu negara dalam mengakumulasi sumberdaya manusia dan proses pembangunan (Khan et al., 2016). Pengeluaran untuk pendidikan dan kesehatan adalah merupakan investasi seperti halnya dengan investasi modal fisik yang akan menghasilkan pengembalian pada masa yang akan datang.

Hal lain yang menarik untuk infrastruktur diagregasi dalam tiga jenis, diperhatikan dari pertumbuhan ekonomi yaitu infrastruktur jalan, infrastruktur listrik regional adalah keterbukaan perdagangan. Pada umumnya daerah-daerah yang menjadi sentra perdagangan internasional memiliki pertumbuhan ekonomi tinggi. Peningkatan ekspor-impor tentunya menuntut ketersediaan infrastruktur dan modal manusia yang baik. Interaksi modal manusia dan keterbukaan perdagangan akan berpengaruh positif terhadap produktivitas faktor produksi. Suatu negara yang menerapkan kebijakan keterbukaan perdagangan akan berpengaruh positif pada terbentuknya hubungan internasional, perluasan pasar ekspor, peningkatan modernisasi teknologi dan pengembangan ilmu pengetahuan, mendorong arus penanaman modal asing serta mencegah terjadinya monopoli pada pasar global (Rahmaddi dan Ichihashi, 2011).

Secara empiris, penelitian mengenai dampak pembangunan infrastruktur, modal manusia dan keterbukaan perdagangan telah banyak dilakukan dan menunjukkan hasil yang positif terhadap pertumbuhan ekonomi dengan mempertimbangkan beberapa faktor terkait kebijakan pemerintah, struktur ekonomi dan masyarakat. Dalam penelitian ini, variabel 
dan infrastruktur kesehatan. Variabel modal manusia diagregasi menggunakan angka harapan hidup dan rata-rata lama sekolah. Sedangkan keterbukaan perdagangan dibentuk dengan membagi total ekspor-impor terhadap PDRB. Penelitian Prasetyo dan Firdaus (2009) mengenai pengaruh infrastruktur terhadap pertumbuhan ekonomi wilayah di Indonesia, menyimpulkan bahwa panjang jalan, listrik, air bersih, stok modal dan tenaga kerja memberikan pengaruh positif dan signifikan terhadap output agregat yang diwakili oleh PDRB per kapita.

Penelitian Sahoo dan Dash (2009) menyelidiki peran infrastruktur terhadap pertumbuhan ekonomi di India selama periode 1970-2006. Secara keseluruhan, hasil penelitian ini mengungkapkan bahwa stok infrastruktur, tenaga kerja dan total investasi memainkan peran penting dalam pertumbuhan ekonomi India. Penelitian Vidyattama (2010) menyelidiki faktor-faktor yang mempengaruhi pertumbuhan pendapatan per kapita provinsi-provinsi di Indonesia dan membahas beberapa masalah terkait perkiraan model pertumbuhan regional dengan menggunakan alat analisis GMM Dynamic Panel Data. Beberapa variabel dalam penelitian seperti keterbukaan perdagangan, panjang jalan, belanja pemerintah daerah, investasi dan rata-rata lama sekolah berpengaruh positif dan signifikan terhadap pertumbuhan ekonomi regional di Indonesia.

Penelitian Temitope dan F. (2013) menyelidiki pengaruh infrastruktur kesehatan, penanaman modal asing dan derajat keterbukaan perdagangan terhadap pertumbuhan ekonomi di Nigeria tahun 1977-2010. Penelitian ini menemukan bahwa terdapat hubungan jangka panjang antara infrastruktur kesehatan dan penanaman modal asing terhadap pertumbuhan ekonomi, sedangkan derajat keterbukaan perdagangan menunjukkan hasil yang negatif terhadap pertumbuhan ekonomi Nigeria. Penelitian Maryaningsih et al. (2014) tentang analisis pengaruh infrastruktur di 33 provinsi di Indonesia menunjukkan bahwa variabel investasi, rata-rata lama sekolah, listrik, panjang jalan, pelabuhan, keterbukaan perdagangan, konsumsi pemerintah menunjukkan hasil penelitian yang signifikan terhadap pertumbuhan ekonomi.

Penelitian Maulana (2015) menganalisis pengaruh modal manusia terhadap pertumbuhan ekonomi regional di Provinsi Jawa Tengah tahun 2008-2012 menggunakan regresi data panel 
dengan metode GLS model fixed effect. Hasil penelitiannya menunjukkan bahwa variabel modal manusia yaitu rata-rata lama sekolah, angka harapan hidup, dana alokasi umum berpengaruh positif dan signifikan terhadap pertumbuhan ekonomi regional di Provinsi Jawa Tengah. Penelitian Keho (2017) menunjukkan hubungan jangka panjang antara stok modal, tenaga kerja, dan keterbukaan perdagangan terhadap pertumbuhan ekonomi Pantai Gading tahun 1965-2014.

Penelitian Chakamera dan Alagidede (2018) menyelidiki pengaruh infrastruktur terhadap pertumbuhan ekonomi di negaranegara Sub Sahara Afrika (SSA). Hasil uji panel data dinamis bahwa terdapat pengaruh positif dan signifikan pembangunan infrastruktur terhadap pertumbuhan ekonomi dengan kontribusi terbesar dari stok infrastruktur seperti jalan raya, listrik dan kesehatan di negara-negara Sub Sahara Afrika. Penelitian Sharma (2018) mengkaji ulang hubungan antara pertumbuhan kesehatan terhadap pertumbuhan ekonomi pada 17 negara maju selama tahun 1870-2013. Hasil estimasi dalam penelitian ini menunjukkan bahwa angka harapan hidup, ratarata lama sekolah, inflasi, investasi, pengeluran pemerintah dan keterbukaan perdagangan berpengaruh signifikan terhadap pertumbuhan ekonomi di 17 negara maju. Penelitian HuchetBourdon et al. (2018) yang menyelidiki pengaruh keterbukaan perdagangan, angka harapan hidup, rata-rata lama sekolah dan investasi juga menunjukkan hasil yang positif dan signifikan terhadap pertumbuhan ekonomi. Dampak pembangunan infrastuktur, modal manusia dan keterbukaan perdagangan menarik untuk dikaji seberapa jauh pengaruhnya dapat digunakan sebagai salah satu instrumen kebijakan pembangunan terutama dalam proses recovery saat krisis melanda. Berdasarkan latar belakang, rumusan masalah yang dibahas dalam penelitian ini adalah apakah faktor-faktor produksi yaitu infrastuktur jalan, infrastruktur listrik, infrastruktur kesehatan mempunyai pengaruh yang signifikan terhadap pertumbuhan ekonomi. Apakah modal manusia yang diproksi dengan menggunakan rata-rata lama sekolah dan angka harapan hidup mempunyai pengaruh signifikan terhadap output. Apakah keterbukaan perdagangan suatu daerah mempunyai pengaruh signifikan terhadap output.

Berdasarkan latar belakang dan rumusan masalah, maka penelitian ini bertujuan untuk: 
(1) memberikan kontribusi berupa pemahaman dan gambaran dari dampak pembangunan infrastruktur, modal manusia dan keterbukaan perdagangan terhadap pertumbuhan ekonomi regional, (2) menganalisa besarnya pengaruh dan kontribusi dari masing-masing jenis infrastruktur dan modal manusia terhadap output antarwilayah di Indonesia, (3) menjelaskan hal yang menjadi penyebab terjadinya kesenjangan antarwilayah di Indonesia diakitkan dengan pembangunan infrastruktur.

\section{METODE PENELITIAN}

Analisis regresi dalam penelitian ini menggunakan data panel. Data panel adalah longitudinal data kombinasi antara data time series dan cross-section. Jika $t$ adalah jumlah observasi dan $n$ adalah jumlah unit crosssection, maka data panel terjadi jika $t>1$ dan $n>$ 1. Jika observasi untuk setiap cross-section sama banyaknya disebut balance panels sedangkan jika tidak sama banyak disebut unbalance panels. Proses kombinasi time series dan cross-section untuk membentuk panel disebut pooling. Menurut Baltagi (2015) keuntungan menggunakan data panel, yaitu pertama mampu menyediakan data yang lebih banyak sehingga menghasilkan degree of freedom yang lebih besar. Kedua, menggabungkan informasi dari data time series dan cross-section yang dapat mengatasi masalah yang timbul ketika terjadi masalah penghilangan variabel (omittedvariabel). Metode data panel memiliki dua pendekatan, yaitu Fixed Effect Model (FEM) dan Random Effect Model (REM). Keduanya dibedakan ada atau tidaknya korelasi antara komponen error dengan peubah bebas.

Fixed Effect Model (FEM) ini menggunakan dummy variable untuk memungkinkan perubahan-perubahan dalam intersep-intersep time series dan cross-section akibat variabel-variabel yang dihilangkan. Intersep hanya hanya bervariasi terhadap individu namun konstan terhadap waktu, sedangkan kecondongannya konstan baik terhadap individu maupun waktu. Jadi $\alpha$, adalah sebuah grup dari spesifik nilai konstan pada model regresi. Formulasi umum model ini mengasumsikan bahwa perbedaan antar unit dapat diketahui dari perbedaan konstannya. Fixed Effect Model (FEM) dapat ditulis sebagai berikut:

$$
y_{i t}+i \alpha_{i}+X_{i} \beta+\varepsilon_{t}
$$

Random Effect Model (REM) ini meningkatan efisiensi proses pendugaan kuadrat terkecil 
dengan memperhitungkan pengganggu- fixed effect model atau diuji secara statistik penggangu time series dan cross-section. tidak berbeda, jelas bahwa random effect model Intersepnya bervariasi terhadap individu akan digunakan karena lebih efisien. Dalam uji dan waktu namun kecondongannya konstan Hausman dirumuskan hipotesis sebagai berikut: terhadap individu maupun waktu. Jadi $\alpha_{i}$ adalah $\quad H_{0}=E\left(\tau_{i} \mid X_{i t}\right)=0$

sebuah gangguan khusus, mirip seperti $\varepsilon_{\mathrm{it}}$ Random Effect Model (REM) adalah model kecuali untuk setiap grup terdapat nilai khusus yang tepat

yang masuk dalam regresi secara identik untuk

$$
H_{1}=E\left(\tau_{i} \mid X_{i t}\right)=0
$$

setiap periode. Nilai $\alpha_{\mathrm{i}}$ terdistribusi secara acak pada unit-unit cross-section. Random Effect tepat

Model (REM) dapat ditulis sebagai berikut:

$$
y_{i t}=\alpha_{i}+\beta^{\prime} X_{i t}+u_{i}+\varepsilon_{i t}
$$

Dengan adalah gangguan acak pada observasi dan konstan sepanjang waktu.

Setelah diketahui bahwa model terdapat heterogenitas individu, selanjutnya diuji apakah heterogenitas itu bersifat fixed effect model atau random effect model. Pengujian kesesuaian model data panel dilatar belakang oleh tradeoff antara bias dan efisisen. Model data panel seperti fixed effect model memang tidak bias tetapi kurang efisien. Dibandingkan dengan random effect model dengan metode GLS dengan diperoleh estimasi parameter yang lebih efisien tetapi tidak bias. Jika perbedaan estimasi parameternya tidak terlalu jauh berbeda baik signifikansi ataupun arah parameternya antara

Fixed Effect Model (FEM) adalah model yang

Sebagai dasar penolakan $\mathrm{H}_{0}$ maka digunakan statistik Hausman dan membandingkan dengan Chi-square. Jika nilai $\mathrm{H}$ hasil pengujian lebih besar dari tabel, maka bukti untuk melakukan penolakan terhadap sehingga model yang digunakan adalah fixed effect, begitu juga sebaliknya.

Analisis yang dilakukan dalam penelitian ini untuk melihat hubungan antara dampak pembangunan infrastruktur, modal manusia, dan keterbukaan perdagangan terhadap pertumbuhan ekonomi regional di Indonesia. Penelitian ini menggunakan metode kuantitatif dan menggunakan ekonometrika data panel. Data panel (pooled) adalah kombinasi data runtun waktu (time series) dan individual (cross-section) (Gujarati dan Porter, 2009). 
Data yang digunakan terdiri dari 34 provinsi di Indonesia selama tahun 2010-2018. Pada tahun 2013-2018 terjadi fenomena perlambatan laju pertumbuhan ekonomi. Fenomena ini menarik itu diamati, karena mengacu pada target Rencana Pembangunan Jangka Menengah Nasional (RPJMN) 2015-2019 bahwa pertumbuhan ekonomi Indonesia ditargetkan berada pada level $7 \%$, tetapi selama kurun waktu 5 tahun terakhir pertumbuhan ekonomi Indonesia tumbuh rata- rata 5\%. Mengingat pada periode sebelumnya pada tahun 2010-2012 pertumbuhan ekonomi Indonesia tumbuh rata-rata $6 \%$.

Model yang digunakan untuk mengestimasi pertumbuhan ekonomi mengacu pada pertumbuhan Solow dan secara empiris model tersebut telah dilakukan penelitian oleh Canning dan Pedroni (2004). Analisis yang dilakukan menggunakan fungsi produksi agregat untuk melihat hubungan antara nilai

Tabel 2.

Operasionalisasi Variabel Penelitian

\begin{tabular}{|c|c|c|c|c|}
\hline No & Variabel & Konsep & Satuan & Sumber \\
\hline 1 & $\begin{array}{l}\text { Petumbuhan } \\
\text { Ekonomi } \\
\text { (PDRB) }\end{array}$ & $\begin{array}{l}\text { Pertumbuhan ekonomi adalah proses kenaikan } \\
\text { output per kapita dalam jangka panjang. }\end{array}$ & Rupiah & $\begin{array}{l}\text { Badan Pusat } \\
\text { Statistik }\end{array}$ \\
\hline 2 & $\begin{array}{l}\text { Infrastruktur } \\
\text { Jalan (JLN) }\end{array}$ & $\begin{array}{l}\text { Infrastruktur jalan merupakan sarana } \\
\text { pendukung bagi kelangsungan penggunaan alat } \\
\text { transportasi. }\end{array}$ & $\mathrm{Km}$ & $\begin{array}{l}\text { Badan Pusat } \\
\text { Statistik }\end{array}$ \\
\hline 3 & $\begin{array}{l}\text { Infrastruktur } \\
\text { Listrik (LIS) }\end{array}$ & $\begin{array}{l}\text { Infrastruktur listrik merupakan sarana yang } \\
\text { dipakai untuk memproduksi dan } \\
\text { membangkitkan tenaga listrik dari berbagai } \\
\text { sumber tenaga. }\end{array}$ & KWh & $\begin{array}{l}\text { Perusahan } \\
\text { Listrik } \\
\text { Negara }\end{array}$ \\
\hline 4 & $\begin{array}{l}\text { Infrastruktur } \\
\text { Kesehatan } \\
\text { (KES) }\end{array}$ & $\begin{array}{l}\text { Infrastruktur kesehatan merupakan sarana } \\
\text { layanan kesehatan yang berguna untuk } \\
\text { meningkatkan produktivitas masyarakat. }\end{array}$ & Unit & $\begin{array}{l}\text { Kementerian } \\
\text { Kesehatan }\end{array}$ \\
\hline 5 & $\begin{array}{l}\text { Rata-Rata } \\
\text { Lama } \\
\text { Sekolah } \\
\text { (RLS) }\end{array}$ & $\begin{array}{l}\text { Rata-rata lama sekolah adalah jumlah tahun } \\
\text { yang digunakan oleh penduduk dalam } \\
\text { menjalani pendidikan formal. }\end{array}$ & Tahun & $\begin{array}{l}\text { Badan Pusat } \\
\text { Statistik }\end{array}$ \\
\hline 6 & $\begin{array}{l}\text { Angka } \\
\text { Harapan } \\
\text { Hidup } \\
\text { (AHH) }\end{array}$ & $\begin{array}{l}\text { Angka harapan hidup adalah rata-rata perkiraan } \\
\text { banyak tahun yang dapat ditempuh oleh } \\
\text { seseorang sejak lahir. }\end{array}$ & Tahun & $\begin{array}{l}\text { Badan Pusat } \\
\text { Statistik }\end{array}$ \\
\hline 7 & $\begin{array}{l}\text { Keterbukaan } \\
\text { Perdagangan } \\
\text { (KP) }\end{array}$ & $\begin{array}{l}\text { Keterbukaan perdagangan adalah kewajiban } \\
\text { impor dan ketegasan pada batasan non-tarif. }\end{array}$ & USD & $\begin{array}{l}\text { Kementerian } \\
\text { Perdagangan }\end{array}$ \\
\hline
\end{tabular}


tambah output (Y) dengan jumlah tenaga kerja (L), jumlah input modal swasta $(\mathrm{K})$, modal publik berupa infrastruktur $(\mathrm{G})$, modal manusia (H) dan keterbukaan perdagangan (TO) dapat dituliskan sebagai berikut:

$$
Y=A f(K, L, G, H, T O)
$$

Dalam hal ini diasumsikan spesifikasi dari model adalah homogen derajat satu untuk semua input $\mathrm{K}, \mathrm{L}, \mathrm{G}, \mathrm{H}$, dan TO. Diasumsikan juga infrastruktur merupakan input bagi produksi agregat, baik sebagai variabel eksogen yang berada di luar persamaan maupun di dalam persamaan (endogenous). Pada penelitian ini akan dilihat bahwa $\mathrm{G}$ mempengaruhi $\mathrm{Y}$ dan merupakan variabel eksogen dan tidak secara langsung menerima pembayaran sebagai faktor produksi dari perusahaan atau sebagai "unpaid factor". Model tersebut akan melihat bagaimana dampak faktor modal publik dalam hal ini infrastruktur dan modal manusia dapat berpengaruh terhadap output. Karena itu model tersebut dapat ditulis dalam fungsi CobbDouglas yang diperluas yaitu sebagai berikut:

$$
Y_{i t}=A_{i t} K_{i t}^{\alpha} L_{i t}{ }^{\beta} G_{i t}{ }^{\mathrm{y}} H_{i t}{ }^{\delta} T O_{i t}{ }^{\Phi}
$$

adalah Produk Domestik Regional Bruto (PDRB) per kapita, adalah total faktor produksi, adalah modal swasta, adalah tenaga kerja, adalah modal infrastruktur, adalah modal manusia, adalah keterbukaan perdagangan pada indeks provinsi $(i)$ dan indeks waktu $(t)$.

Persamaan (7) dapat ditulis kembali dalam bentuk sebagai berikut:

$L n Y_{i t}=a+\alpha L n K_{i t}+\beta L n L_{i t}+L n G_{i t}+\delta L n H_{i t}+\Phi L n T O_{i t}$

Secara teori diketahui bahwa parameter $\alpha, \beta, \gamma, \delta, \Phi$, dan $\psi$ merupakan nilai elastisitas output terhadap modal swasta, tenaga kerja, modal publik, modal manusia serta eksporimpor. Pada fungsi Cobb-Douglas, berlaku substitusi antar faktor di mana dimungkinkan pendugaan skala usaha dari nilai elastisitas masing-masing faktor (return to scale). Produksi agregat dikatakan mencapai kondisi pada skala konstan atau constant return to scale, pada saat $\alpha+\beta+\gamma+\delta=1$. Apabila $\alpha+\beta+\gamma$ $+\delta<1$ dikatakan kondisi yang dicapai adalah berada pada skala menurun (decreasing return to scale), dan jika $\alpha+\beta+\gamma+\delta>1$, dikatakan mencapai kondisi skala menaik (increasing return to scale). Pemilihan operasional model disesuaikan dengan ketersedian data dan satuan variabel dependen dan variabel independen ditransformasikan ke dalam bentuk logaritma natural (Ln) sehingga data regresi berdistribusi normal. 
Dalam analisis empiris akan dilihat pengaruh infrastruktur, modal manusia dan keterbukaan perdagangan terhadap pertumbuhan ekonomi regional di Indonesia. Analisis ini bertujuan untuk melihat pengaruh infrastruktur, modal manusia dan keterbukaan perdagangan dalam peningkatan output pada provinsiprovinsi di Indonesia, dan bias kebijakan pemerintah terhadap pengeluaran publik seperti infrastruktur dan modal manusia. Kemudian kedua ruas dari dua persamaan di atas dibagi dengan variabel modal swasta $(\mathrm{K})$ dan tenaga kerja (L), karena batasan dalam penelitian ini menggunakan variabel infrastruktur, modal manusia dan keterbukaan perdagangan. Kedua persamaan ini dapat ditulis sebagai berikut:

$$
L n Y_{i t}=\alpha_{t}+\beta L n G_{i t}+\delta L n H_{i t}+\Phi L n T O_{i t}+u_{i t}
$$

Dimana $u$ merupakan error term. Dalam perhitungan untuk variabel $G$ (infrastruktur) akan diagregasi dalam tiga jenis infrastruktur (stock) dan untuk variabel $\mathrm{H}$ modal manusia akan diagregasi dalam dua jenis modal manusia sehingga persamaan (9) dapat ditulis sebagai berikut:

$$
L n Y_{i t}=\alpha_{t}+\Sigma \beta L n G_{i t}+\Sigma \delta L n H_{i t}+u_{i t}
$$

Dimana persamaan (10dioperasionalkan dalam bentuk sebagai berikut:
$L n P D R B_{i t}=\beta_{0}+\beta_{1} \operatorname{LnJLN}_{i t}+\beta_{2} \operatorname{LnLIS}_{i t}+$ $\beta_{3} \operatorname{LnKES}_{i t}+\beta_{4} \operatorname{LnRLS} S_{i t}+\beta_{5} \operatorname{LnAHH} H_{i t}+\beta_{6} \operatorname{LnKP_{it}}$ $+u_{i t}$ (10)

Di mana LnPDRB adalah PDRB per kapita ADHK 2010, LnJLN yaitu panjang jalan provinsi berdasarkan tingkat kewenangan, LnLIS yaitu kapasitas terpasang yang dibangkitkan, LnKES yaitu jumlah tempat tidur rumah sakit, LnRLS yaitu rata-rata lama sekolah, LnAHH yaitu angka harapan hidup, LnKP yaitu keterbukaan perdagangan, i yaitu provinsi, $\mathrm{t}$ yaitu tahun dan $\mathrm{u}$ adalah error term. Operasionalisasi variabel penelitian diperlukan agar tidak terjadi pemaknaan ganda terhadap penelitian sehingga pengukuran dapat dilakukan dengan tepat. Operasionalisasi variabel dalam penelitian ini terdapat pada Tabel 1. Jenis data yang digunakan dalam penelitian ini menggunakan data sekunder yang bersumber dari Badan Pusat Statistik, Kementerian Perdagangan, Perusahaan Listrik Negara dan Kementerian Kesehatan. Data dalam penelitian ini menggunakan analisis data panel dengan time series 2010-2018 dan 34 provinsi di Indonesia sebagai cross-section.

\section{HASIL DAN PEMBAHASAN}

Dalam penelitian ini, model yang digunakan 
untuk mengestimasi pengaruh infrastruktur, keterbukaan perdagangan. Jumlah observasi modal manusia dan keterbukaan perdagangan yang digunakan sebanyak 306 sampel dari 34 mengacu pada model penelitian Canning dan provinsi di Indonesia dengan rentang waktu Pedroni (2004) yang meneliti tentang "The 2010-2018.

Effect of Infrastructure on Long Run Economic

Growth". Model tersebut pengembangan model pertumbuhan Solow dengan asumsi teknologi dan kualitas tenaga kerja dianggap konstan. Investasi dalam penelitian ini memasukkan investasi fisik berupa infrastruktur dan investasi sumber daya manusia. Infrastruktur diagregasi menjadi 3 variabel yaitu infrastrukur jalan, infrastruktur listrik dan infrastruktur kesehatan, sedangkan modal manusia diagregasi menggunakan rata-rata lama sekolah dan angka harapan hidup.

Variabel dependen dalam penelitian ini adalah pertumbuhan ekonomi regional, Provinsi Jawa Timur dengan angka logaritma sedangkan variabel independen adalah natural 10.658 atau $42.555 \mathrm{Km}$, sedangkan infrastruktur listrik, infrastrukur kesehatan, yang terendah pada tahun 2016 adalah Provinsi rata-rata lama sekolah, angka harapan hidup dan DI Yogyakarta dengan angka logaritma natural

Tabel 3.

Statistik Deskriptif

\begin{tabular}{lllllll}
\hline \multicolumn{1}{c}{ Variable } & Obs & Mean & Median & Maximum & Minimum & Std. Dev. \\
\hline LnPDRB & 306 & 17.170525 & 17.11571 & 19.44104 & 10.23511 & 0.796506 \\
LnJLN & 306 & 9.439051 & 9.519184 & 10.65855 & 8.236421 & 0.649845 \\
LnLIS & 306 & 7.811968 & 7.751245 & 9.134892 & 6.987093 & 0.403453 \\
LnKES & 306 & 8.423872 & 8.347590 & 10.66378 & 6.234411 & 0.992518 \\
LnRLS & 306 & 3.996327 & 4.234903 & 1.314015 & 1.874874 & 0.670337 \\
LnAHH & 306 & 2.303795 & 2.086293 & 4.315085 & 1.720979 & 0.697622 \\
LnKP & 306 & 1.554427 & 1.640937 & 5.241800 & -3.912023 & 1.833600 \\
\hline
\end{tabular}

PDRB per kapita ADHK 2010 pada tahun 2010-2018 memiliki rata-rata dalam bentuk logaritma natural 17.170 atau Rp35.558. Provinsi dengan PDRB per kapita tertinggi pada tahun 2018 adalah Provinsi DKI Jakarta dengan angka logaritma natural 18.926 atau Rp16.586, sedangkan yang terendah pada tahun 2010 adalah Provinsi Nusa Tenggara Timur dengan angka logaritma natural 16.047 atau Rp9.316. Panjang jalan pada tahun 2010-2018 memiliki rata-rata dalam bentuk logaritma natural 9.439 atau 15397.2 Km. Provinsi yang memiliki panjang jalan tertinggi pada tahun 2013 adalah Sumber: Data Diolah 
8.236 atau $3.776 \mathrm{Km}$. Listrik yang dibangkitkan pada tahun 2010-2018 memiliki rata-rata dalam bentuk logaritma natural dengan angka 7.811 atau 2719.8 KWh. Provinsi yang memiliki pembangkit listrik tertinggi pada tahun 2013 adalah Provinsi DKI Jakarta dengan logaritma natural 9.134 atau 9273.28 KWh, sedangkan yang terendah pada tahun 2013 adalah Provinsi Nusa Tenggara Timur dengan angka logaritma natural 6.987 atau $1082.57 \mathrm{KWh}$.

Tempat tidur rumah sakit pada tahun 2010-2018 memiliki rata-rata dalam bentuk logaritma natural 8.423 atau 7818.07 unit. Provinsi yang memiliki tempat tidur rumah sakit tertinggi tahun 2013 adalah Provinsi Jawa Tengah dengan angka logaritma natural 10.663 atau 42.778 unit, sedangkan yang terendah pada tahun 2010 dengan angka logaritma natural 6.234 atau 510 unit dimiliki oleh Provinsi Gorontalo. Rata-rata lama sekolah pada tahun 2010-2018 mempunyai rata-rata dalam bentuk logaritma natural 3.996 atau 69.00 tahun. Provinsi yang mempunyai rata-rata lama sekolah tertinggi adalah Provinsi DKI Jakarta dengan angka logaritma natural 4.285 atau 11.05 tahun pada tahun 2018, sedangkan yang terendah adalah Provinsi Papua dengan angka logaritma natural
4.160 atau 5.59 tahun pada tahun 2010.

Angka harapan hidup pada tahun 20102018 memiliki rata-rata dalam bentuk logaritma natural 2.303 atau 7.96 tahun. Provinsi yang memiliki angka harapan hidup tertinggi adalah Provinsi DI Yogyakarta pada tahun 2018 dengan angka logaritma natural 2.232 atau 74.82 tahun, sedangkan yang terendah adalah Provinsi Nusa Tenggara Barat tahun 2010 dengan angka logaritma natural 1.745 atau 63.82 tahun. Keterbukaan perdagangan pada tahun 20102018 memiliki rata-rata dalam bentuk logaritma natural 1.554 atau 16.199. Provinsi yang memiliki keterbukaan perdagangan tertinggi adalah Provinsi Jawa Barat tahun 2010 dengan angka logaritma natural 5.241 atau 189.01, sedangkan yang terendah adalah Provinsi Papua tahun 2017 dengan angka logaritma natural 1.609 atau 0.02 .

Uji Hausman adalah pengujian statistik sebagai dasar pertimbangan memilih model yang terbaik apakah menggunakan fixed effect model atau random effect model (Gujarati dan Porter, 2009).

Berdasarkan Tabel 4 menunjukkan bahwa nilai prob. Cross-section random $<\alpha$ (0.05) atau $0.0000<0.05$, maka model yang 
digunakan adalah Fixed Effect Model (FEM).

Model penelitian yang akan diestimasi adalah model yang menjelaskan analisis pengaruh infrastruktur, modal manusia dan keterbukaan perdagangan terhadap pertumbuhan ekonomi regional di Indonesia. Variabel infrastruktur yang akan dianalisis pengaruhnya adalah infrastruktur jalan, infrastruktur listrik dan infrastruktur kesehatan. Variabel modal manusia yang akan dianalisis pengaruhnya adalah angka harapan hidup dan rata-rata lama sekolah. Sedangkan variabel keterbukaan perdagangan adalah total ekspor-impor terhadap PDRB. Dalam penelitian ini menggunakan n sebanyak 306 sampel, sehingga $n \geq 30$ data dianggap berdistribusi normal. Semakin besar nilai n, maka aproksimasi central limit theorem akan semakin akurat atau semakin mendekati distribusi normal (Gujarati and Porter, 2009). Hasil estimasi lain dalam penelitian ini, terbebas dari masalah multikolinearitas sempurna, tidak terdapat masalah heterokedastisitas dan tidak terjadi masalah autokorelasi.
Hasil estimasi variabel-variabel independen pada Tabel 5 adalah sebagai berikut: angka harapan hidup mempunyai elastisitas terbesar yaitu 0.91; rata-rata lama sekolah 0.87; tempat tidur rumah sakit 0.23; listrik 0.07; keterbukaan perdagangan 0.007 . Model dari persamaan di atas mempunyai nilai Adjusted R-squared sebesar 0.98 yang artinya model yang disusun mampu menjelaskan variasi pertumbuhan ekonomi regional sebesar 98.91\%. Sedangkan pada masing-masing variabel independen yang signifikan dapat diinterpretasikan sebagai berikut:

Modal manusia dalam penelitian ini diproksi menggunakan angka harapan hidup. Metode fixed effect menunjukkan bahwa angka harapan hidup berpengaruh positif dan signifikan terhadap pertumbuhan ekonomi regional. Angka harapan hidup memiliki nilai koefisien sebesar 0.91 pada tingkat signifikansi 1 persen. Artinya, bahwa setiap kenaikan angka harapan hidup sebesar 1 persen akan meningkatkan pertumbuhan ekonomi regional

Tabel 4.

Uji Hausman

\begin{tabular}{lccc}
\hline Test Summary & Chi-Sq. Statistic & Chi-Sq. d.f. & Prob. \\
\hline Cross-section random & 27.250919 & 6 & 0.0001 \\
\hline
\end{tabular}

Sumber: Data Diolah 
Tabel 5.

Hasil Estimasi Dengan Menggunakan Fixed Effect Model

\begin{tabular}{ccccc}
\hline Variable & Coefficient & Std. Error & t-Statistic & Prob. \\
\hline C & $9.516663^{* * *}$ & 0.745966 & 12.75751 & 0.0000 \\
LnJLN & -0.062915 & 0.061245 & -1.027259 & 0.3052 \\
LnLIS & $0.078416^{* * *}$ & 0.032402 & 2.420105 & 0.0162 \\
LnKES & $0.239361^{* * *}$ & 0.020939 & 11.43122 & 0.0000 \\
LnRLS & $0.879687^{* * *}$ & 0.142522 & 6.172279 & 0.0000 \\
LnAHH & $0.917935^{* * *}$ & 0.140940 & 6.512943 & 0.0000 \\
LnKP & $0.007548^{* *}$ & 0.003893 & -1.938960 & 0.0536 \\
\hline Adjusted -squared & & 0.989121 & \\
F-Statistic & & 712.0367 & \\
Prob. (F-Statistic) & & 0.000000 & \\
\hline
\end{tabular}

* Signifikan pada 10\%, ** Signifikan pada 5\%, *** Signifikan pada 1\%

Sumber: Data Diolah

0.91 persen, ceteris paribus. Hasil penelitian ini Artinya, bahwa setiap kenaikan rata-rata sejalan dengan penelitian yang telah dilakukan lama sekolah 1 persen akan meningkatkan oleh Sharma (2018) dan Huchet-Bourdon et pertumbuhan ekonomi regional sebesar 0.87 al. (2018), yang mengatakan bahwa angka persen, ceteris paribus. Hasil penelitian ini harapan hidup adalah pembangunan manusia sejalan dengan penelitian yang telah dilakukan yang termasuk konsep ekonomi, karena salah satu konsep pembangunan ekonomi adalah peningkatan mutu modal manusia salah satunya melalui kesehatan. Tingginya angka harapan hidup akan berpengaruh pada produktivitas tenaga kerja menjadi semakin baik dan yang semakin tinggi memiliki kaitan yang berdampak pada pertumbuhan ekonomi.

oleh Vidyattama (2010); Maryaningsih et al. (2014);Huchet-Bourdon et al. (2018), yang mengatakan bahwa rata-rata lama sekolah berpengaruh positif dan signifikan terhadap pertumbuhan ekonomi. Tingkat pendidikan Variabel rata-rata lama sekolah teknologi untuk mempermudah pemenuhan memberikan pengaruh positif dan signifikan berbagai kebutuhan taraf hidup yang terus terhadap pertumbuhan ekonomi regional. Rata- meningkat. rata lama sekolah memiliki nilai koefisien Variabel infrastruktur kesehatan sebesar 0.87 pada tingkat signifikansi 1 persen. menunjukkan hasil yang positif dan signifikan 
terhadap pertumbuhan ekonomi regional. esensial terutama untuk perusahaan, institusi Infrastruktur kesehatan memiliki koefisien atau organisasi yang berkepentingan dengan sebesar 0.23 dengan tingkat signifikansi 1 peningkatan sumber daya manusia yang persen. Artinya, bahwa setiap kenaikan jumlah berdampak pada pertumbuhan ekonomi.

tempat tidur rumah sakit sebesar 1 persen Variabel infrastruktur listrik memberikan akan meningkatkan pertumbuhan ekonomi pengaruh positif dan signifikan terhadap regional sebesar 0.23 persen, ceteris paribus. pertumbuhan ekonomi regional. Infrastruktur Hasil penelitian ini sejalan dengan penelitian listrik memiliki nilai koefisien sebesar 0.07 Sahoo dan Dash (2009)we investigate the dan signifikan pada tingkat 1 persen. Artinya, role of infrastructure in economic growth in bahwa setiap kenaikan 1 persen infrastruktur India for the period 1970-2006 on the basis of listrik akan meningkatkan pertumbuhan the empirical framework developed by D.A. ekonomi sebesar 0.07 persen, ceteris paribus. Aschauer (Is public expenditure productive? Hasil penelitian ini sejalan dengan penelitian Journal of monetary economics, 23 (2; Temitope yang dilakukan Sahoo dan Dash (2009); dan F. (2013); Chakamera dan Alagidede Temitope dan F. (2013); Chakamera dan (2018); Sharma (2018), yang mengatakan Alagidede (2018), yang mengatakan bahwa bahwa fasilitas kesehatan merupakan hal paling infrastruktur listrik merupakan salah satu dominan dalam menyumbang kualitas sumber bentuk energi terpenting dalam perkembangan daya manusia. Dengan adanya infrastruktur manusia modern, baik untuk kegiatan rumah kesehatan merupakan salah satu faktor kunci tangga, pendidikan, kesehatan, usaha, industri dari tercapainya pembangunan kesehatan. maupun kegiatan lainnya dari mulai komunitas Akses layanan infrastruktur kesehatan yang pengguna di kota besar sampai pelosok daerah. lengkap dan terjangkau di suatu negara atau Produksi barang dan jasa akan lebih efektif dan wilayah akan membuat ketahanan kesehatan efisien dengan hadirnya alat-alat modern yang masyarakat, meningkatkan produktivitas, menggunakan energi listrik yang dampaknya kesempatan kerja serta upah akan semakin akan meningkatkan pertumbuhan ekonomi tinggi. Tersedianya infrastruktur menjadi sifat secara signifikan. 
Variabel keterbukaan perdagangan independen berpengaruh positif terhadap menunjukkan hasil yang positif dan signifikan pertumbuhan ekonomi regional, kecuali terhadap pertumbuhan ekonomi regional. infrastruktur jalan memberikan pengaruh Keterbukaan perdagangan mempunyai nilai yang negatif dan tidak signifikan. Angka koefisien sebesar 0.007 dengan tingkat harapan hidup memberikan kontribusi terbesar signifikansi 5 persen. Artinya setiap peningkatan keterbukaan perdagangan sebesar 5 persen akan meningkatkan pertumbuhan ekonomi sebesar 0.007 persen, ceteris paribus. Hasil penelitian ini sejalan dengan penelitian yang telah dilakukan oleh Vidyattama (2010); Temitope dan F. (2013); Maryaningsih et al. (2014); Huchet-Bourdon et al. (2018), yang mengatakan bahwa perdagangan yang tinggi berimplikasi pada semakin besarnya keterbukaan yang membutuhkan teknik produksi yang efisien, mengarah pada pertumbuhan produktivitas faktor produksi yang lebih cepat dan pada gilirannya pada kenaikan pendapatan per kapita.

\section{SIMPULAN DAN SARAN}

Simpulan dari beberapa hasil temuan dari penelitian ini adalah pendugaan parameter persamaan pertumbuhan ekonomi regional di Indonesia memperlihatkan bahwa infrastruktur, modal manusia dan keterbukaan perdagangan memberikan pengaruh pada tingkat signifikansi 1 persen dan 5 persen. Hampir semua variabel terhadap pertumbuhan ekonomi regional. Dari hasil ini dapat disimpulkan bahwa investasi pada sumberdaya manusia mempunyai peran penting sebagai pelaku maupun sebagai sasaran pembangunan. Prioritas lainnya adalah semakin tinggi rata-rata lama sekolah di suatu daerah akan meningkatkan akses dan daya saing pendidikan. Investasi pada infrastruktur listrik akan meningkatkan efisiensi berproduksi dan investasi pada infrastruktur kesehatan akan meningkatkan perbaikan status kesehatan, termasuk peningkatan akses pada layanan fasilitas kesehatan. Untuk faktor non investasi fisik dan sumberdaya manusia, keterbukaan perdagangan memberikan pengaruh positif dan signifikan terhadap pertumbuhan ekonomi regional. Hasil penelitian ini dapat dijadikan pemicu bagi provinsi-provinsi di Indonesia untuk meningkatkan volume perdagangan, baik perdagangan antar negara atau perdagangan antar provinsi.

Saran untuk penelitian selanjutnya 
adalah model dalam penelitian ini dapat lebih disempurnakan dengan memperbaiki kualitas data yang digunakan seperti data mikro level distrik atau level individu. Implikasi kebijakan yang dapat dilakukan ada beberapa usulan kepada pemerintah selaku pengambil kebijakan, yaitu meningkatkan akselerasi investasi modal manusia dan modal fisik yang berkontribusi besar terhadap pertumbuhan ekonomi regional dimulai dari memperbaiki status kesehatan masyarakat, meningkatkan kualitas pendidikan dasar dan menengah, meningkatkan aksesibilitas infrastruktur listrik ke daerah tertinggal, terdepan dan terluar, meningkatkan akses dan kualitas layanan kesehatan serta meningkatkan keterbukaan perdagangan untuk mengurangi rent-seeking yang mengahlihkan sumberdaya dari aktivitas yang menghasilkan pertumbuhan ekonomi.

\section{REFERENSI}

Baltagi, B. H. (2015). Econometric Analysis of Panel Data (5th Ed.). Chicester: John Wiley \& Sons Ltd.

Canning, D., \& Pedroni, P. (2004). The Effect of Infrastructure On Long Run Economic Growth. Harvard University, 1-30. Retrieved from https://ideas.repec.org/p/ wil/wileco/2004-04.html

Chakamera, C., \& Alagidede, P. (2018). The
Nexus Between Infrastructure (Quantity and Quality) and Economic Growth in Sub Saharan Africa. International Review of Applied Economics, 32(5), 641672. https://doi.org/10.1080/02692171.2 017.1355356

Dasha, R. K., \& Sahoo, P. (2010). Economic Growth in India: The Role of Physical and Social Infrastructure. Journal of Economic Policy Reform, 13(4), 373385. https://doi.org/10.1080/17487870. 2010.523980

Farah, A., \& Sari, E. P. (2014). Modal Manusia Dan Produktivitas. Journal of Economics and Policy, 7(1), 22-28. https://doi. org/10.15294/jejak.v7i1.3840

Gujarati, D. N., \& Porter, D. C. (2009). Basic Econometrics (5th ed.). New York: McGraw-Hill Higher Education Publishing. Huchet-Bourdon, M., Le Mouël, C., \& Vijil, M. (2018). The Relationship Between Trade Openness and Economic Growth: Some New Insights On The Openness Measurement Issue. World Economy, 41(1), 59-76. https://doi.org/10.1111/ twec. 12586

Keho, Y. (2017). The Impact of Trade Openness On Economic Growth: The case of Cote d'Ivoire. Cogent Economics and Finance, 5(1), 1-14. https://doi.org/10.10 80/23322039.2017.1332820

Khan, H. N., Razali, R. B., \& Shafei, A. B. (2016). On The Relationship Between Health, Education and Economic Growth: Time Series Evidence from Malaysia. AIP Conference Proceedings, 1787. https://doi.org/10.1063/1.4968146

Maryaningsih, N., Hermansyah, O., \& Savitri, M. (2014). Pengaruh Infrastruktur terhadap Pertumbuhan ekonomI IndonesIa. Buletin Ekonomi Moneter Dan Perbankan, 17(1), 62-98. https://doi. org/10.21098/bemp.v17i1.44

Maulana, R. (2015). Pengaruh Human Capital Terhadap Pertumbuhan Ekonomi Regional di Provinsi Jawa Tengah. Economics Development Analysis Journal, 
4(2), 159-165.

Otto, A., Hall, J. W., Hickford, A. J., Nicholls, R. J., Alderson, D., Barr, S., \& Tran, M. (2014). A Quantified System-of-Systems Modeling Framework for Robust National Infrastructure Planning. IEEE Systems Journal, 10(2), 385-396. https:// doi.org/10.1109/jsyst.2014.2361157

Panennungi, M. A., \& Xu, N. (2017). Perekonomian Indonesia dalam Tujuh Neraca Makroekonomi (1st ed.). Jakarta: Yayasan Pustaka Obor Indonesia.

Prasetyo, R. B., \& Firdaus, M. (2009). Pengaruh Infrastruktur Pada Pertumbuhan Ekonomi Wilayah Di Indonesia. Jurnal Ekonomi Dan Kebijakan Pembangunan, 2, 222-236. Retrieved from http://repository.ipb.ac.id/handle/123456789/53638

Rahmaddi, R., \& Ichihashi, M. (2011). Exports and Economic Growth in Indonesia: A Causality Approach based on Multi-Variate Error Correction Model. Journal of International Development and Cooperation, 17(2), 53-73. https:// doi.org/10.15027/31352

Sahoo, P., \& Dash, R. K. (2009). Infrastructure Development and Economic Growth In India. Journal of the Asia Pacific Economy, 14(4), 351-365. https://doi. org/10.1080/13547860903169340

Sharma, R. (2018). Health and economic growth: Evidence from dynamic panel data of 143 years. PLoS ONE, 13(10), 1-20. https://doi.org/10.1371/journal. pone. 0204940

Temitope, A., \& F., S. B. (2013). Effect of Private Sector Investment on Economic Growth in Nigeria. IOSR Journal of Economics and Finance, 1(2), 39-47. https://doi.org/10.12816/0033095

Vidyattama, Y. (2010). A Search for Indonesia's Regional Growth Determinants. ASEAN Economic Bulletin, 27(3), 281. https:// doi.org/10.1355/ae27-3c

World Bank. (2018). Indonesia Economic Quarterly: Strengthening Competitiveness. 